\title{
Physiological quality of soybean seeds treated with different spray volumes ${ }^{1}$
}

\author{
Samantha Rigo Segalin², Ana Paula Piccinin Barbieri3*, Caroline Huth ${ }^{3}$, \\ Manoela Beche ${ }^{3}$, Nilson Matheus Mattioni ${ }^{3}$, Liliane Marcia Mertz ${ }^{4}$
}

\begin{abstract}
The aim of this study was to define the influence of treatments with different seed spray volumes and their effects on the physical and physiological quality. The soybean seeds from cultivars NA 5909 RG and BMX Potência RR were used and three lots of each cultivar were selected in sieves of different diameters $(5.5 ; 6.0$ and $6.5 \mathrm{~mm})$. The treatments consisted of different seed volumes: 1) non-treated seeds; 2) $600 \mathrm{~mL} .100 \mathrm{~kg}$ of seeds ${ }^{-1}$; 3) $800 \mathrm{~mL} .100 \mathrm{~kg}$ of seeds ${ }^{-1}$; 4) 1000 $\mathrm{mL} .100 \mathrm{~kg}$ of seeds $\mathrm{s}^{-1}$; 5) $1200 \mathrm{~mL} .100 \mathrm{~kg}$ of seeds ${ }^{-1}$; 6) $1400 \mathrm{~mL} .100 \mathrm{~kg}$ of seeds ${ }^{-1}$. The physical parameters evaluated were mechanical damage, water content and variations in the length and width of the seeds. The physiological seed quality was determined by germination, first count germination, length and dry weight of seedlings, field emergence and emergence speed index tests. In terms of use of the product in liquid form, it is possible to use the treatment in spray volumes up to $1400 \mathrm{~mL} .100$ $\mathrm{kg} \mathrm{seed}^{-1}$, regardless the cultivar or seed size and without damaging the soybean seeds physically and physiologically.
\end{abstract}

Index terms: Glycine max L., seed treatment, seed size, germination.

\section{Parâmetros físicos e qualidade fisiológica de sementes de soja tratadas com diferentes volumes de calda}

\begin{abstract}
RESUMO - O objetivo do trabalho foi determinar a influência de diferentes volumes de calda, via tratamento de sementes, nos parâmetros físicos e na qualidade fisiológica de sementes de soja. Foram utilizadas as cultivares NA 5909 RG e BMX Potência RR, sendo três lotes de cada cultivar, os quais foram classificados em peneiras de diferentes diâmetros $(5,5 ; 6,0$ e $6,5 \mathrm{~mm})$. Os tratamentos consistiram na utilização de diferentes volumes de calda: 1) testemunha sem tratamento; 2) $600 \mathrm{~mL} .100 \mathrm{~kg}$ de sementes $^{-1}$; 3) $800 \mathrm{~mL} .100 \mathrm{~kg}$ de sementes $^{-1}$; 4) $1000{\mathrm{~mL} .100 \mathrm{~kg} \text { de sementes }}^{-1}$; 5) $1200 \mathrm{~mL} .100 \mathrm{~kg}$ de sementes ${ }^{-1}$; 6) $1400 \mathrm{~mL} .100$ $\mathrm{kg}$ de sementes ${ }^{-1}$. Os parâmetros físicos avaliados foram dano mecânico, teor de água e variações no comprimento e largura das sementes. A qualidade fisiológica das sementes foi determinada pelos testes de germinação, primeira contagem da germinação, comprimento e fitomassa seca de plântulas, emergência a campo e índice de velocidade de emergência. Em condições de utilização dos produtos em forma líquida, independente da cultivar ou do tamanho da semente, é possível utilizar o tratamento em volumes de calda de até $1400 \mathrm{~mL} .100 \mathrm{~kg}$ de sementes ${ }^{-1}$, sem que ocorram danos físicos e fisiológicos às sementes de soja.
\end{abstract}

Termos para indexação: Glycine max, tratamento de semente, tamanho de sementes, germinação.

\section{Introduction}

Soybean is the main oil seed cultivated worldwide and its production stands out in the national scenario, being one of the most important commodities of the Brazilian agribusiness. The use of soybean in the biofuel, oil and food industries requires productivity developments.

The soybean yield potential may be affected by several factors, including the attack of plagues and microorganisms. The use of phytosanitary products, such as fungicides and

${ }^{1}$ Submitted on $05 / 02 / 2013$. Accepted for publication on $08 / 19 / 2013$.

${ }^{2}$ Departamento de Fitotecnia, UFPel, Caixa Postal 354, 96001-970 Pelotas, RS, Brasil. insecticides applied in the seeds, guarantees the protection of seeds and seedlings in the early stage of germination (Ludwig et al., 2011; Pereira et al., 2011).

Thus, the seed treatment is a widespread technology, considering that, for soybeans, the volume of seeds treated with fungicides is approximately $95 \%$ (Henning et al., 2010). Several products have been applied directly in the seed, aiming at protecting them against fungus and bugs, diseases transmitted by seeds, micronutrients, growth regulators, inoculants, besides the using polymers for a greater adherence

${ }^{3}$ Departamento de Fitotecnia, UFSM, 97105-900 - Santa Maria, RS, Brasil. ${ }^{4}$ Embrapa Soja, Caixa Postal 231, 86001-970 - Londrina, PR, Brasil.

*Corresponding author < apaulabarbieri@yahoo.com.br> 
of products (Ávila et al., 2008; Avelar et al., 2011; Ludwig et al., 2011; Dourado-Neto et al., 2012). This variety of products causes the spray volume to be higher than $600 \mathrm{~mL} .100 \mathrm{~kg}^{-1}$ of seeds. This value is indicated as maximum tolerated volume of liquid so there is no damage, such as rupture of the soybean seed skin, which may impair the germination and the physical properties of the seeds (Embrapa, 2011).

Nowadays, products used for the seeds treatment contain liquid formulas with greater permeation potential. Therefore, explanatory studies indicate the possibility of using larger spray volumes without the production of negative effect of the physiological performance of the seeds (Krzyzanowski et al., 2007).

The seeds vulnerability to damages occurred due to a larger use of spray volume in the seeds treatment may be influenced by factors such as their physiological quality, and also, the variations in seed sizes. According to a study conducted by Beckert et al. (2000), the water absorption is deeper in smaller soybean seeds; that may be related with their physiological potential. A faster water absorption process may cause damage due to impregnation. The classification of soybean seeds according to their sizes after the cleaning process has been adopted by several producers because it improves the sowing process (Camozzato et al., 2009).

Thus, this study aims at defining the influence of different spray volumes, through the seeds treatment, on the physical characteristics and the physiological potential of soybean seeds classified in sieves of different diameters.

\section{Material and Methods}

The research was held in Seed Laboratory of the Plant Science Department at Universidade Federal de Santa Maria. Two soybean cultivars were used, NA 5909 RG and BMX Potência RR, harvested on 2011/2012 and cultivated in the region of Santa Maria (RS). The lots of each cultivar were classified in sieves of three different sizes, 5.5; 6.0 and $6.5 \mathrm{~mm}$. The seed quality was characterized based on the following tests:

Water Content: defined by oven method at $105 \pm 3{ }^{\circ} \mathrm{C}$, during 24 hours, with three subsamples from each lot, as recommended in the Rules for Seed Testing (Brasil, 2009).

Weight of one thousand seeds: eight subsamples of 100 seeds were used. The result was expressed in grams in accordance with the Rules for Seed Testing (Brasil, 2009).

Mechanical damage: the sodium hypochlorite test was performed, with four replications of 50 seeds for each cultivar and sieve size. The seeds were immersed in a solution with $5.25 \%$ sodium hypochlorite during 10 minutes; after that, the number of swollen seeds was calculated. The results were expressed in percentage of swollen seeds or mechanically damaged seeds (Krzyzanowski et al., 2004).

Germination: four replications of 100 seeds were sowed over two towel paper sheets, covered with a third sheet and wrapped up. The germination paper was moistened with distilled water at a ratio of 2.5 times the weight of the dry paper. The rolls were kept in a germinator at $25^{\circ} \mathrm{C}$. The evaluations were made five and eight days after the seeding, as established by Brasil (2009). The results were expressed in percentage of normal seedlings.

Field emergence: it was conducted with four replications of 100 seeds, sowed in $2.0 \mathrm{~m}$ long rows, with $0.20 \mathrm{~m}$ between them at $0.03 \mathrm{~m}$ depth. The evaluation of the seedling emergence percentage was made seven days after sowing.

Emergencespeedindex: in order to establish this characteristic, the seedlings emerged after the emergence tests were counted daily. The index was calculated with the equation described by Maguire (1962) and mentioned by Nakagawa (1994): IVE $=\mathrm{E}_{1} /$ $\mathrm{N}_{1}+\mathrm{E}_{2} / \mathrm{N}_{2}+\ldots \mathrm{E}_{\mathrm{n}} / \mathrm{N}_{\mathrm{n}}$, where IVE = emergence speed index; $\mathrm{E}_{1}$, $\mathrm{E}_{2}$ e $\mathrm{E}_{\mathrm{n}}=$ number of seedlings emerged on the first, second and umpteenth counting; $\mathrm{N}_{1}, \mathrm{~N}_{2}$ e $\mathrm{N}_{\mathrm{n}}=$ number of days.

Tetrazolium test: four replications of 50 seeds for each cultivar and sieve size were used, in accordance with the method described by França-Neto et al. (1998). The samples were placed on paper towels, dampened with distilled water in a quantity that was 2.5 times more than their weight, during 16 hours at $25^{\circ} \mathrm{C}$. After that, the seeds were placed in plastic containers and kept in a solution with $0.075 \%$ of chloride of 2 , 3,5 trifeniltetrazolium, at $40{ }^{\circ} \mathrm{C}$ in the dark, for 150 minutes. After this period, the seeds were washed in running water and analyzed one by one. The number of vigorous (vigour) seeds, included in classes 1 to 3 , and the number of seeds that were likely to germinate (viability), included in classes 1 to 5 , was accounted. The results were expressed in percentage of viability and vigor.

After the chacarcterization of the seeds quality, they were submitted to treatment with different spray volumes.

Initially, in order to obtain different spray volumes, the maximum volume was specified and the other volumes were obtained from it, by a reduction of the doses de bio-stimulating and by the removal of products that had not presented effect on the physiological seed quality in the laboratory, such as inoculants, micronutrients and liquid polymers (Pereira et al., 2009).

The products used were: fungicide Carbendazim + Thiram $\left(\right.$ Derosal Plus $\left.{ }^{\mathbb{}}\right)$; insecticide Imidacloprido + Tiodicarbe $\left(\right.$ Cropstar $\left.^{\mathbb{R}}\right)$, liquid fertilizer molybdenum $(15 \%)$ and Cobalt $(1.5 \%)\left(\right.$ Agromix $\left.^{\circledR}\right)$, liquid polymer (Polifix Laborsan $\left.{ }^{\circledR}\right)$, liquid inoculants with approximately $3 \times 10^{9}$ feasible cells 
by millimeter (Nitragin Cell Tech $\mathrm{HC}^{\circledR}$ ) and soluble biostimulating, cytokine $0.009 \%+$ gibberellin $0.005 \%+$ auxin
$0.005 \%$ (Stimulate $\left.{ }^{\circledR}\right)$. The respective dosages used are described in Table 1.

Table 1. Products used for the soybean seeds treatment and respective dosages, for attainment of different spray volumes. Fungicide (F), insecticide (I), bio-stimulating (B), micronutrient (M), polymer (P) e inoculant (I).

\begin{tabular}{ccccccccc}
\hline \multirow{2}{*}{ Treatments } & F & I & B & M & P & I & Water & Total \\
\cline { 2 - 8 } & & - & - & - & - & - & - & - \\
\hline 1 & 200 & 200 & 200 & - & - & - & - & -100 \\
2 & 200 & 200 & 300 & - & - & 100 & - & 800 \\
3 & 200 & 200 & 400 & - & 100 & 100 & - & 1000 \\
4 & 200 & 200 & 400 & 200 & 100 & 100 & - & 1200 \\
5 & 200 & 200 & 400 & 200 & 100 & 100 & 200 & 1400 \\
$6^{*}$ & & &
\end{tabular}

*For the sixth treatment, the spray volume was complemented with $200 \mathrm{~mL}$ of water.

The seeds treatment had the following order: fungicide, insecticide, bio-stimulating, micronutrient, polymer and inoculants. It was made in 3 liter plastic bags, with 500 grams of seeds in each bag.

After the treatments, the seeds were submitted to germination, water content, field emergence and emergence speed index tests, as previously described, besides the additional specifications, described below, in order to verify the effect of spray volume on the physiological quality of seedlings.

Seedling length: four subsamples with 15 seeds were sowed on the upper part of the towel paper. The paper rolls were moistened with distilled water in a ratio of 2.5 times the weight of the dry paper, and then kept in a germinator at $25^{\circ} \mathrm{C}$. The evaluations were made seven days after the sowing, and the upper part, roots and total length of ten normal seedlings were measured. The results were expressed in cm.seedling-1 (Nakagawa, 1999).

Dry weight of seedlings: the cotyledons of each seedling resultant from the evaluation of the seedlings length test were removed. After that, the seedlings were packed in paper bags and put to dry in an oven at $80{ }^{\circ} \mathrm{C}$, during 24 hours. After this period, the samples were weighed in order to define the total dry weight of seedlings. The result was expressed in mg.seedling-1 (Nakagawa, 1999).

Seeds length: measured with a digital caliper rule, in the embryo direction, with four replications of 25 seeds for each treatment. The results were expressed in milimiter $(\mathrm{mm})$.

Seeds width: measured with a digital caliper rule, on the central part of the seed, perpendicular to the length measure, with four replications of 25 seeds for each treatment. The results were expressed in $\mathrm{mm}$.

All the evaluations were made completely random desing. For the initial classification of the seeds, the treatments were organized in a factorial $2 \times 3$ (cultivars $\times$ sieve sizes), the variables were submitted to variance analyses and the means were compared by the Scott Knott test at $5 \%$ of significance, with the software Sisvar (Ferreira, 2008). For the spray volume effect, the treatments were organized in a factorial $2 \times 3 \times 6$ (cultivars $\times$ sieve size $\times$ spray volume) with four replications. The variance analysis was made by software Action, the means comparison with non-treated seeds was made by the Dunnett test, with $5 \%$ of probability. Additionally, the regression equations of the variables were adjusted, having as

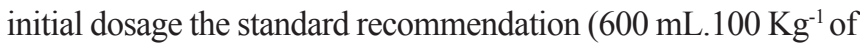
seeds), with the aid of the statistical program Sisvar.

\section{Results and Discussion}

By the initial classification of the seed lots (Table 2), it is possible to note that for both cultivars, the $5.5 \mathrm{~mm}$ sieve presented a low germination percentage, even though they seemed feasible after the tetrazolium test. Such seeds did not reach the minimum percentage required for the commercialization of soybean seeds in Brazil, which is $80 \%$ (Brasil, 2005). Although the studies performed so far have presented conflicting results regarding the relation between seeds size and physiological quality, unfavorable climate conditions of the seeds production region during the harvest of 2011/2012 need to be considered. Thus, the seeds from the $5.5 \mathrm{~mm}$ sieve may present bigger problems during the maturation and reserves accumulation, causing a reduction in their physiological quality.

The soybean seeds from 6.0 and $6.5 \mathrm{~mm}$ sieves presented higher germination values for both cultivars (Table 2). These results are in agreement with Pádua et al. (2010), who observed the physiological quality differences regarding the seeds size; bigger seeds present higher germination and vigor percentages. The bigger or heavier seeds usually hold embryos that are steadily grown and have more reserves, being potentially more vigorous (Carvalho and Nakagawa, 2000). 
Table 2. Initial classification of the soybean seeds quality from two cultivars, classified in sieves of different diameters (mm). Median values of the results of water content (WC\%) weight of one thousand seeds (OTS, g), mechanical damage (MD\%), germination (G\%), field emergence (FE\%), emergence speed index (ESI), Viability (VIAB\%) and vigour (V\%).

\begin{tabular}{cccccccccc}
\hline Cultivar & Size & WC & OTS & MD & G & FE & ESI & VIAB & V \\
\hline \multirow{2}{*}{ NA 5909 RG } & 5.5 & $11.14 \mathrm{a}$ & $127.99 \mathrm{c}$ & $4 \mathrm{a}$ & $57 \mathrm{c}$ & $57 \mathrm{a}$ & $9.26 \mathrm{a}$ & $90 \mathrm{a}$ & $80 \mathrm{~b}$ \\
& 6.0 & $10.77 \mathrm{~b}$ & $153.72 \mathrm{~b}$ & $15 \mathrm{~b}$ & $87 \mathrm{~b}$ & $46 \mathrm{~b}$ & $6.94 \mathrm{~b}$ & $94 \mathrm{a}$ & $88 \mathrm{a}$ \\
& 6.5 & $10.35 \mathrm{c}$ & $180.64 \mathrm{a}$ & $15 \mathrm{~b}$ & $94 \mathrm{a}$ & $55 \mathrm{a}$ & $8.67 \mathrm{a}$ & $92 \mathrm{a}$ & $76 \mathrm{~b}$ \\
\hline \multirow{3}{*}{ BMX Potência RR } & 5.5 & $11.81 \mathrm{a}$ & $110.15 \mathrm{c}$ & $2 \mathrm{a}$ & $69 \mathrm{~b}$ & $78 \mathrm{a}$ & $13.18 \mathrm{a}$ & $96 \mathrm{a}$ & $90 \mathrm{a}$ \\
& 6.0 & $11.06 \mathrm{~b}$ & $139.29 \mathrm{~b}$ & $4 \mathrm{~b}$ & $93 \mathrm{a}$ & $78 \mathrm{a}$ & $12.52 \mathrm{a}$ & $100 \mathrm{a}$ & $94 \mathrm{a}$ \\
& 6.5 & $10.78 \mathrm{c}$ & $170.42 \mathrm{a}$ & $6 \mathrm{~b}$ & $96 \mathrm{a}$ & $71 \mathrm{~b}$ & $11.53 \mathrm{a}$ & $95 \mathrm{a}$ & $96 \mathrm{a}$ \\
\hline
\end{tabular}

*Measures followed by the same letter in the column do not differ inwardly by the Scott \& Knott test, $p>0,05$.

On the other side, this physiological quality variation among the different lots is important for the results obtained from different treatments to be used in lots with vigor level variations.

The water content values were similar among the cultivars and the sizes (Table 2). Even though there was a statistical difference, they were not higher than $1 \%$, which does not wield influence over the other variables analyzed.

Regarding the weight of one thousand seeds, significant differences were observed among the sieve sizes. The heavier seeds were removed in the $6.5 \mathrm{~mm}$ sieve, followed by the seeds with $6.0 \mathrm{~mm}$ and $5.5 \mathrm{~mm}$ diameters, respectively. The relation between the size and weight observed was as expected; however, several aspects are responsible for this characteristic, such as environmental conditions and genetic differences (Camozzato et al., 2009; Egli, 2012).

The evaluation of mechanical damages in the seeds by the sodium hypochlorite test showed that less damage percentages were found in smaller sieves for both cultivars (Table 2). Also, in cultivar NA 5909 RG, the seeds from 6.0 and $6.5 \mathrm{~mm}$ sieves presented more than $10 \%$ of mechanical damage. Such values are considered to be critical (Krzyzanowski et al., 2004), which may significantly reduce the performance of soybean seeds (Obando Flor et al., 2004). Bigger seeds are more likely to suffer mechanical damage, especially during the mechanical harvest. Besides that, different results among cultivars are expected due to the physical characteristics of each cultivar. That explains the use of more than one cultivar in the studies.

The tetrazolium test indicated higher physiological quality of seeds from the $6.0 \mathrm{~mm}$ sieve, in cultivar NA 5909 RG. For cultivar BMX Potência RR there were no differences in the vigor and feasibility of seeds considering the sieve sizes evaluated.

Tables 3 and 4 show the physiological quality data of the seeds that were submitted to different spray volumes, compared with the non-treated seeds. Regardless the cultivar or the seed sizes, the treatments with different spray volumes not only did not affect the initial development of the seedlings negatively, but also improved most physiological characteristics analyzed (germination, first count germination, length and dry weight of seedlings), mainly in low quality lots (5.5 $\mathrm{mm}$ sieves).

The seeds treatment protects the seeds and their seedlings against diseases and bug plagues, maintaining the physiological and sanitary quality of the seed during the storage (Avelar et al., 2011), contributing to a proper initial establishment and the production increase (Gadotti et al., 2012). Moreover, Balardin et al. (2011) observed that treating seeds with insecticides and fungicides benefits the plants, increasing their tolerance to hydric stress, with a positive effect over the soybean yield potential.

Except for the non-treated seeds, in the other treatments the percentage of normal seedlings in the germination was higher, which means the treatment with larger spray volumes did not cause a phytotoxic effect on the seeds and no abnormalities occurred (Tables 3 e 4). According to Sediyama et al. (2012), the soaking of seeds during the germination in liquids, other than water, promotes a slow hydration, allows more time for membranes repair and rearrangement, lowers the lixiviation of solution by the seed and the risks of damage in the embryo caused by a fast soaking, promoting a significant influence on the seeds germination and vigor percentage.

Considering the field emergence, the treated seeds presented, mostly, a greater performance when compared with the non-treated seeds. According to Lima et al. (2006), the germination test is performed under ideal conditions of temperature and humidity unlike the field emergence. As Goulart (1998) describes, the soybean seed begins its germination process and emerges quickly on soils with adequate temperature and humidity. Whenever such conditions are not met, the process is slower, which causes the soil and seed funguses to attack and ruin the seeds or even kill the seedling. That explains the difference between the germination and field emergence test results. 
Table 3. Means of cultivar NA 5909 RG for germination (G\%), upper part length (UPL, cm), root length (RL, $\mathrm{cm}_{\text {.seedling }}^{-1}$ ) and total length (TL, cm.seedling ${ }^{-1}$ ), dry weight of seedlings (DW, g.seedling ${ }^{-1}$ ), field emergence (FE\%) and emergence speed index (SEI), evaluated in three seed sizes and six spray volumes.

\begin{tabular}{|c|c|c|c|c|c|c|c|c|}
\hline Size & Volume & $\mathrm{G}$ & UPL & $\mathrm{RL}$ & TL & DW & FE & SEI \\
\hline \multirow{6}{*}{5.5} & 0 & 57 & 11.21 & 13.96 & 25.18 & 0.261 & 38 & 5.81 \\
\hline & 600 & $88^{*}$ & 13.21 & $16.39 *$ & $29.60 *$ & 0.281 & $70 *$ & $11.4^{*}$ \\
\hline & 800 & $77 *$ & 12.64 & $17.88^{*}$ & $30.52 *$ & 0.305 & $61^{*}$ & $9.79^{*}$ \\
\hline & 1000 & $88^{*}$ & 11.55 & $18.47^{*}$ & $30.02 *$ & 0.270 & 53 & 8.89 \\
\hline & 1200 & $92 *$ & 12.21 & $19.52 *$ & $31.73 *$ & 0.282 & $56^{*}$ & 8.30 \\
\hline & 1400 & $95^{*}$ & 11.72 & $18.77 *$ & $30.49 *$ & 0.312 & $67 *$ & $11.4^{*}$ \\
\hline \multirow{6}{*}{6.0} & 0 & 87 & 9.87 & 16.74 & 26.61 & 0.338 & 43 & 6.91 \\
\hline & 600 & $94 *$ & 11.44 & 17.47 & 28.91 & 0.351 & $65^{*}$ & 9.84 \\
\hline & 800 & 90 & 8.73 & 19.37 & 28.10 & 0.328 & 47 & 7.51 \\
\hline & 1000 & 91 & 6.72 & 14.53 & 21.25 & 0.306 & 48 & 6.64 \\
\hline & 1200 & $92 *$ & 7.71 & 14.99 & 22.71 & 0.352 & 38 & 5.96 \\
\hline & 1400 & $92 *$ & 10.40 & 17.84 & 28.25 & 0.340 & 36 & 4.81 \\
\hline \multirow{6}{*}{6.5} & 0 & 94 & 10.81 & 17.59 & 28.40 & 0.351 & 45 & 6.97 \\
\hline & 600 & 94 & 9.76 & 15.63 & 25.39 & 0.337 & 50 & 7.29 \\
\hline & 800 & 94 & $8.09 *$ & $11.37 *$ & $19.46^{*}$ & $0.296^{*}$ & 59 & 9.91 \\
\hline & 1000 & 91 & 11.31 & $14.58^{*}$ & 25.89 & 0.349 & 69 & 10.11 \\
\hline & 1200 & 93 & $8.29 *$ & $14.16^{*}$ & $22.46^{*}$ & $0.309^{*}$ & 58 & 9.55 \\
\hline & 1400 & 96 & $7.50 *$ & $11.97 *$ & $19.47 *$ & $0.288^{*}$ & 51 & 8.18 \\
\hline
\end{tabular}

*Significant with 5\% of overshoot probability by Dunnett's test.

Table 4. Means of cultivars BMX Potência RR for germination (G\%), upper part length (UPL, cm), root length (RL, cm.seedling ${ }^{-1}$ ) and total length (TL, cm.seedling ${ }^{-1}$ ), dry weight of seedlings (DW, g.seedling $\left.{ }^{-1}\right)$, field emergence (FE\%) and emergence speed index (SEI), evaluated in three seed sizes and six spray volumes.

\begin{tabular}{|c|c|c|c|c|c|c|c|c|}
\hline Size & Volume & G & UPL & RL & TL & DW & $\mathrm{FE}$ & SEI \\
\hline \multirow{6}{*}{5.5} & 0 & 69 & 12.94 & 16.68 & 29.63 & 0.29 & 89 & 15.5 \\
\hline & 600 & $84 *$ & 13.30 & 15.99 & 29.29 & 0.32 & 76 & 13.7 \\
\hline & 800 & $91^{*}$ & 11.16 & 16.74 & 27.90 & 0.29 & 76 & 13.1 \\
\hline & 1000 & $87 *$ & 12.74 & 16.64 & 29.38 & 0.30 & 75 & 12.5 \\
\hline & 1200 & $93 *$ & 14.09 & 16.20 & 30.29 & 0.29 & 76 & 12.6 \\
\hline & 1400 & $95^{*}$ & 12.96 & 17.40 & 30.36 & 0.27 & 76 & 11.8 \\
\hline \multirow{6}{*}{6.0} & 0 & 94 & 10.52 & 16.83 & 27.36 & 0.37 & 80 & 14.2 \\
\hline & 600 & 96 & $7.01 *$ & 17.37 & 24.39 & $0.29 *$ & 77 & 10.6 \\
\hline & 800 & 94 & 10.76 & 16.25 & 27.01 & 0.36 & 91 & 15.1 \\
\hline & 1000 & 95 & 10.18 & 17.58 & 27.77 & 0.35 & 80 & 12.2 \\
\hline & 1200 & 94 & $7.08 *$ & 17.61 & 24.69 & $0.31^{*}$ & 74 & 12.5 \\
\hline & 1400 & 92 & $15.06^{*}$ & 15.41 & 30.48 & 0.40 & 69 & 10.7 \\
\hline \multirow{6}{*}{6.5} & 0 & 96 & 11.69 & 16.79 & 28.48 & 0.37 & 77 & 13.9 \\
\hline & 600 & 95 & 10.50 & $13.75^{*}$ & $24.25^{*}$ & 0.34 & 75 & 10.9 \\
\hline & 800 & 94 & 13.08 & 15.00 & 28.09 & 0.39 & 72 & 11.3 \\
\hline & 1000 & 94 & 10.28 & 17.81 & 28.09 & 0.34 & 76 & 11.4 \\
\hline & 1200 & $91^{*}$ & 11.25 & $12.82 *$ & $24.07 *$ & 0.34 & 65 & 11.1 \\
\hline & 1400 & 94 & 11.74 & 14.87 & 26.61 & 0.36 & 62 & 10.7 \\
\hline
\end{tabular}

*Significant with $5 \%$ of overshoot probability by Dunnett's test.

Based on these results, it is possible to infer that for liquid products it is possible to use up to $1400 \mathrm{~mL}$ of spray volume for the treatment of $100 \mathrm{~kg}$ of soybean seeds without affecting their physiological performance negatively, in laboratory as well as field studies. In this case, the evaluations refer to the treatment held before the sowing, without the storage aspect 
into consideration. These data are compatible with the one observed by Krzyzanowski et al. (2007), in a soybean seed research that enabled the complete treatment, with high spray volumes for evaluations in high and low vigor lots inside the laboratory or the greenhouse.

Regarding the seeds humidity (Table 5), for both cultivars and sieve sizes, the water content increased around $1 \%$ in the spray volumes considered. That shows the treatments tested did not cause damage to this parameter, for, even with this increase, the seeds humidity remained under $13 \%$, which is considered adequate for storage and sowing, without mechanical damages due to crush. On the other hand, in this study, the initial water content of the seeds was around $11 \%$ (Table 2). Whenever the initial humidity is close to $13 \%$, the humidity increase may not be safe, especially for storage.

Table 5. Means of cultivars NA 5909 RG and BMX Potência RR for the characteristics of water content (WC, \%), width (W, $\mathrm{mm}$.seedling $\mathrm{I}^{-1}$ ) and length $\left(\mathrm{L}, \mathrm{mm}\right.$.seedling $\left.{ }^{-1}\right)$, evaluated in three seed sizes and six spray volumes.

\begin{tabular}{cccccccc}
\hline \multirow{2}{*}{ Size } & \multicolumn{2}{c}{ NA 5909 RG } & \multicolumn{3}{c}{ BMX Potência RR } \\
\cline { 2 - 7 } & Volume & WC & W & L & WC & W & L \\
& 0 & 11.14 & 5.57 & 6.42 & 11.80 & 5.69 & 7.36 \\
& 600 & 11.30 & 5.55 & 6.51 & $12.09^{*}$ & 5.58 & 7.24 \\
5.5 & 800 & 11.21 & 5.64 & 6.41 & $12.24^{*}$ & 5.63 & 7.34 \\
& 1000 & 11.40 & $5.60^{*}$ & 6.46 & $12.07^{*}$ & 5.48 & 7.11 \\
& 1200 & 11.35 & $5.67^{*}$ & 6.49 & $12.06^{*}$ & 5.51 & 7.28 \\
& 1400 & 11.49 & $5.68^{*}$ & 6.66 & $12.26^{*}$ & 5.48 & $7.30^{*}$ \\
\hline & 0 & 10.77 & 6.09 & 6.95 & 11.06 & 6.49 & 7.55 \\
& 600 & $11.19^{*}$ & $6.18^{*}$ & 6.88 & $11.58^{*}$ & 6.21 & 7.59 \\
& 800 & $11.46^{*}$ & $6.14^{*}$ & 6.96 & $11.48^{*}$ & 6.18 & 7.54 \\
& 1000 & $11.57^{*}$ & $6.17^{*}$ & 6.84 & $11.35^{*}$ & 6.20 & 7.57 \\
& 1200 & $11.54^{*}$ & $6.18^{*}$ & 6.86 & 11.01 & 6.21 & 7.60 \\
& 1400 & $11.70^{*}$ & $6.20^{*}$ & 6.93 & 11.21 & 6.20 & 7.61 \\
\hline & 0 & 10.35 & 6.52 & 7.40 & 10.78 & 6.56 & 7.72 \\
& 600 & 10.46 & 6.51 & 7.31 & $11.15^{*}$ & 6.59 & 7.82 \\
& 800 & $11.02^{*}$ & 6.60 & 7.33 & $11.47^{*}$ & 6.64 & $7.96^{*}$ \\
& 1000 & $11.20^{*}$ & 6.64 & 7.62 & $11.29^{*}$ & 6.61 & 7.90 \\
& 1200 & $11.16^{*}$ & 6.58 & 7.29 & $11.25^{*}$ & 6.64 & 7.81 \\
& 1400 & $11.15^{*}$ & 6.55 & 7.33 & $11.18^{*}$ & 6.57 & 7.79 \\
\hline
\end{tabular}

*Significant with $5 \%$ of overshoot probability by Dunnett's test.

Working with soybean seeds, Pereira et al. (2011) did not detect any relevant difference between the humidity degree of seeds treated with fungicides and polymer and the non-treated seeds. This effect may be related with the reestablishment of the seeds hygroscopic balance with the relative air humidity. Regarding the seeds width, for the higher spray volumes in some cases, the treated seeds presented greater width than non-treated seeds (Table 5). However, the values did not surpass the next sieve size tested. That means there is no need to change the seeder disc to sow the seeds treated with different spray volumes.
The regression analysis graphs (Figures 1 and 2) show that for most variables, no equation degree was in accordance with the data observed, considering as standard the maximum spray volume recommended (600 mL) (Embrapa, 2011). So, there was no difference between the spray volumes testes related with the physiological quality of the seeds. For the variables with adjustment, it was possible to note a quadratic behavior, without a behavior trend. Thus, it is not possible to say that increasing the spray volume based on the standard dosage $(600 \mathrm{~mL}$ by $100 \mathrm{Kg}$ of seeds) may improve or spoil the seeds quality. 

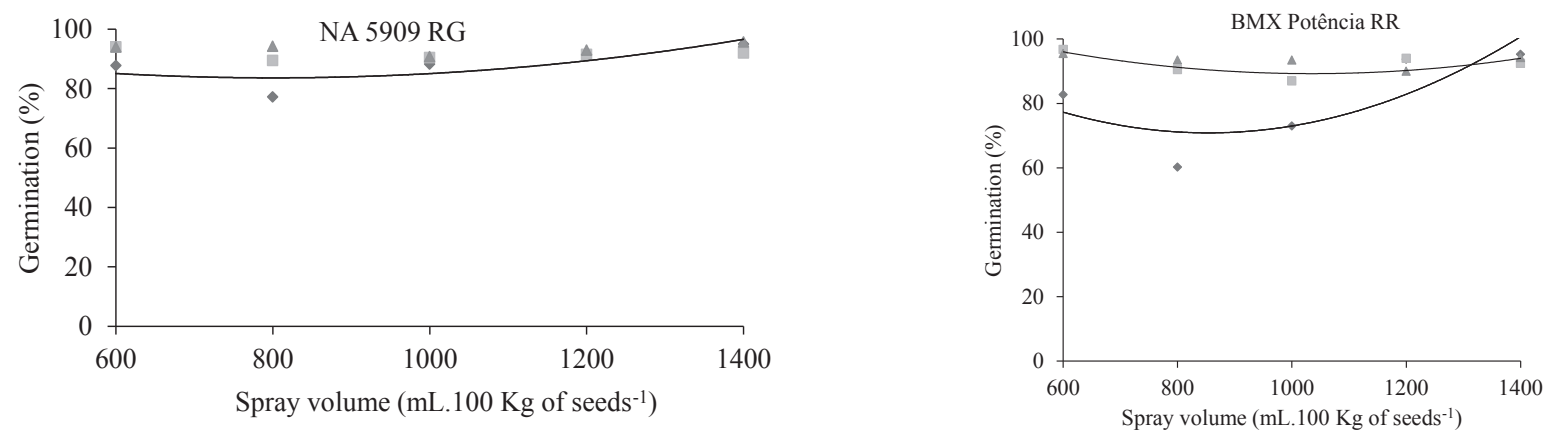

- $5.5 \mathrm{~mm}: \mathrm{y}=0.000036 \mathrm{x}^{2}-0.0579 \mathrm{x}+106.84 \mathrm{R}^{2}=0.63$

- $6.0 \mathrm{~mm}: \overline{\mathrm{y}}=91.50$

$\triangle 6.5 \mathrm{~mm}: \overline{\mathrm{y}}=93.55$
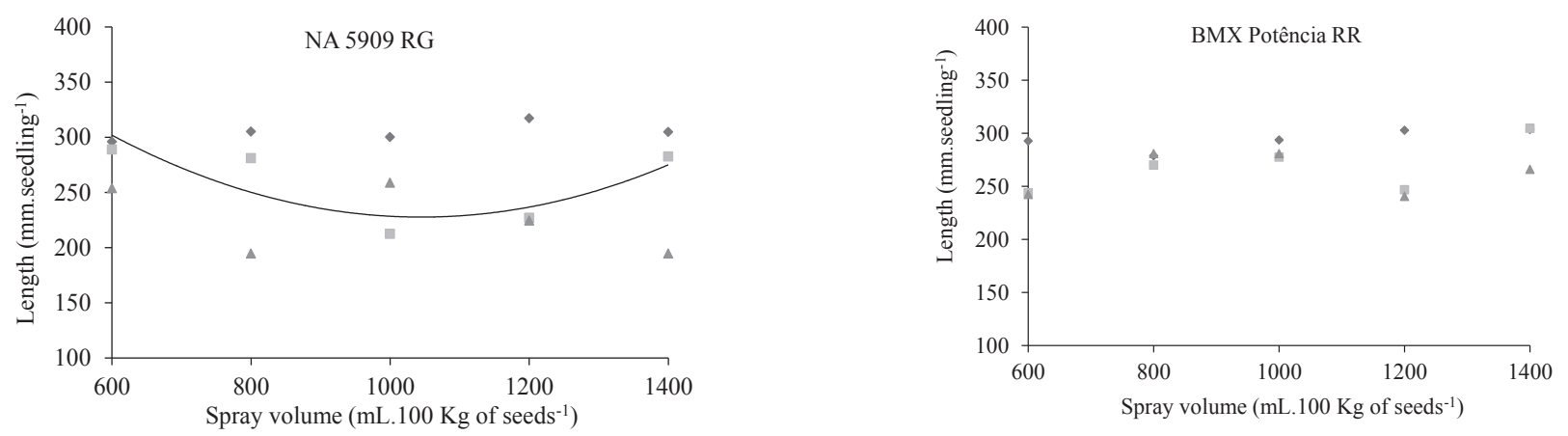

- $5.5 \mathrm{~mm}: \overline{\mathrm{y}}=0.000038 \mathrm{x}^{2}-0.0784 \mathrm{x}+63.74 \mathrm{R}^{2}=0.70$

$6.0 \mathrm{~mm}: \overline{\mathrm{y}}=304.0$

$\triangle 6.5 \mathrm{~mm}: \overline{\mathrm{y}}=225.0$

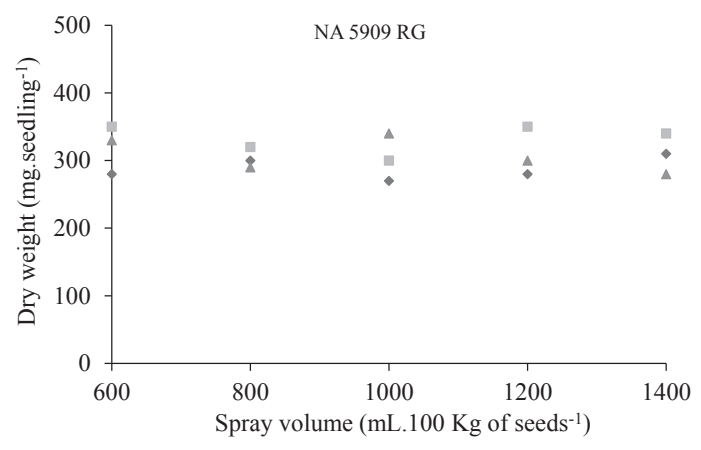

- $5.5 \mathrm{~mm}: \overline{\mathrm{y}}=294.0$

$\square 6.0 \mathrm{~mm}: \overline{\mathrm{y}}=268.0$

$\triangle 6.5 \mathrm{~mm}: \overline{\mathrm{y}}=262.0$

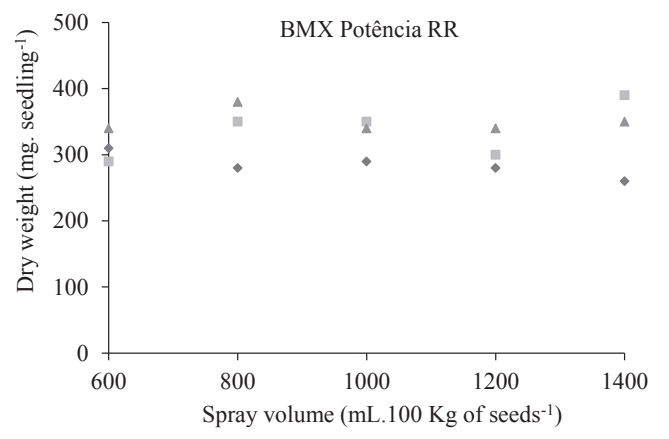

- $5.5 \mathrm{~mm}: \overline{\mathrm{y}}=310.0$

$6.0 \mathrm{~mm}: \overline{\mathrm{y}}=340.0$

- $5.5 \mathrm{~mm}: \overline{\mathrm{y}}=280.0$

$\square .0 \mathrm{~mm}: \overline{\mathrm{y}}=330.0$

$\triangle 6.5 \mathrm{~mm}: \overline{\mathrm{y}}=350.0$

Figure 1. Germination (\%), total length (mm.seedling $\left.{ }^{-1}\right)$, dry weight $\left(\mathrm{mg}_{\text {.seedling }}{ }^{-1}\right)$ of cultivar NA 5909 RG and BMX Potência RR seeds, classified in three sieve sizes, submitted to five spray volumes in the seeds treatment (mL.100 $\mathrm{Kg}^{-1}$ of seeds). 

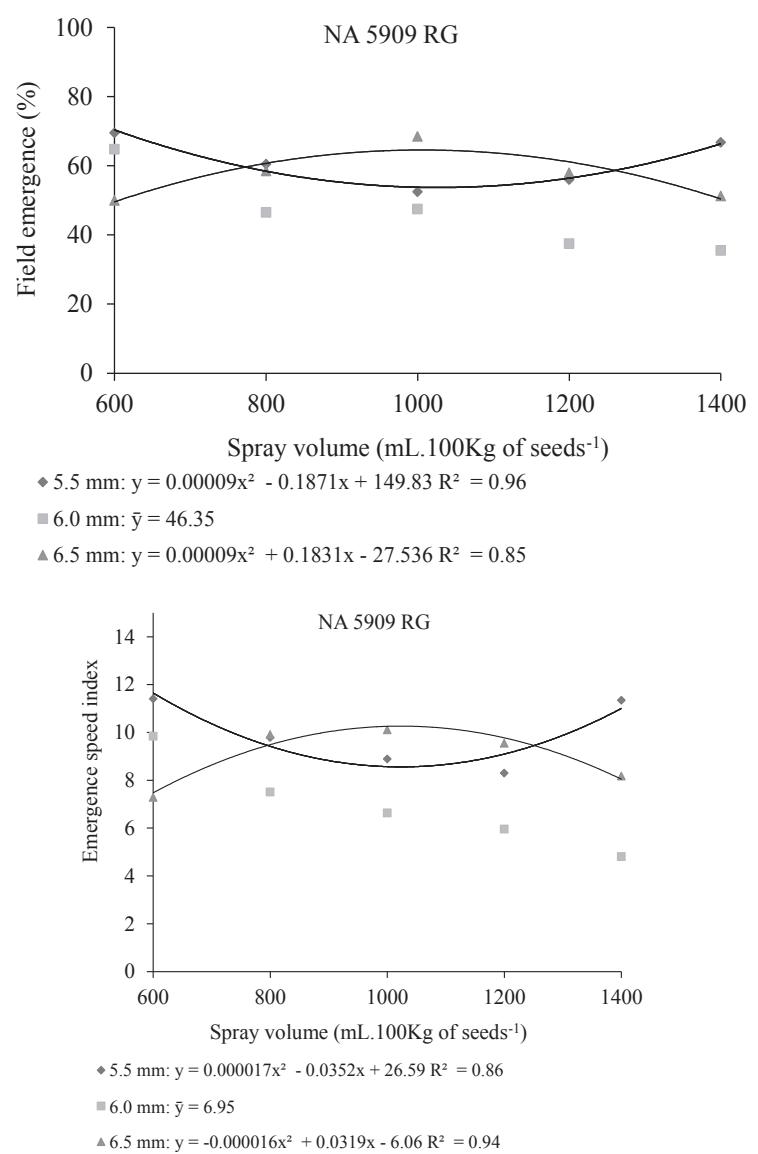
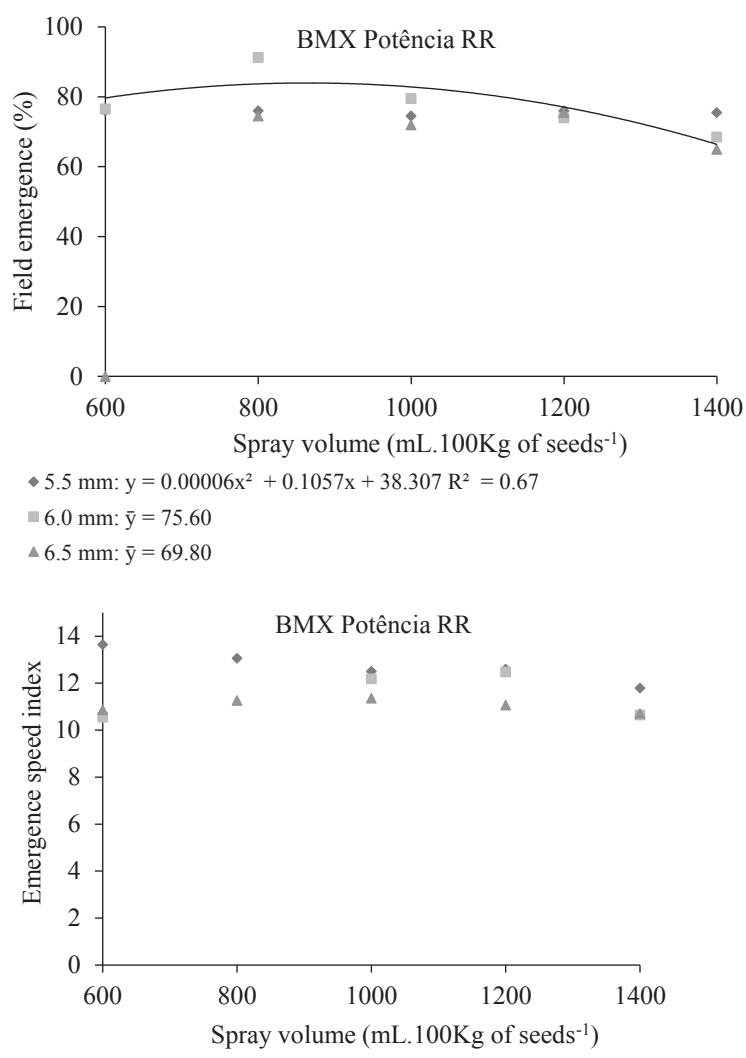

- $5.5 \mathrm{~mm}: \overline{\mathrm{y}}=12.72$

$6.0 \mathrm{~mm}: \overline{\mathrm{y}}=12.19$

$\triangle 6.5 \mathrm{~mm}: \overline{\mathrm{y}}=11.05$

Figure 2. Field emergence (\%) and emergence speed index of cultivar NA 5909 RG and BMX Potência RR seeds, classified in three sieve sizes, submitted to five spray volumes in the seeds treatment (mL.100 Kg ${ }^{-1}$ of seeds).

\section{Conclusion}

For the product in liquid form, regardless the cultivar or seed size, it is possible to use the treatment in spray volumes up to $1400 \mathrm{~mL}$ per $100 \mathrm{~kg}$ of seeds, without causing physical and physiological damage to the soybean seeds.

\section{References}

AVELAR, S.A.G.; BAUDET, L.; PESKE, S.T.; LUDWIG, M.P.; RIGO, G.A.; CRIZEL, R.L.; OLIVEIRA, S. Storage of soybean seed treated with fungicide, insecticide and micronutrient and coated with liquid and powered polymer. Ciência Rural, v.41, n.10, p.1719-1725, 2011. http://www.scielo.br/ scielo.php?pid=S0103-84782011001000007\&script=sci_arttext

ÁVILA, M.R.; BRACCINI, A.L.; SCAPIM, C.A.; ALBRECHT, L.P.; TONIN, T.A.; STÜLP, M. Bioregulator application, agronomic efficiency, and quality of soybean seeds. Scientia Agricola, v.65, n.6, p.604-612, 2008. http://www. scielo.br/scielo.php?script $=$ sci_arttext\&pid=S0103-90162008000600006

BALARDIN, R.S.; SILVA, F.D.L.; DEBONA, D.; CORTE, G.D.; FAVERA, D.D.; TORMEN, N. R. Tratamento de sementes com fungicidas e inseticidas como redutores dos efeitos do estresse hídrico em plantas de soja. Ciência Rural, v.41, n.7, p.1120-1126, 2011. http://www.scielo.br/pdf/cr/v41n7/a5711cr4207.pdf
BECKERT, O.P.; MIGUEL, M.H.; MARCOS-FILHO, J. Absorção de água e potencial fisiológico em sementes de soja de diferentes tamanhos. Scientia Agricola, v.57, n.4, 2000. http://www.scielo.br/scielo.php?pid=S0103$90162000000400012 \&$ script $=$ sci_arttext

BRASIL. Ministério da Agricultura, Pecuária e Abastecimento. Regras para análise de sementes. Ministério da Agricultura, Pecuária e Abastecimento. Secretaria de Defesa Agropecuária. Brasília: MAPA/ACS, 2009. 395p. http:// www.bs.cca.ufsc.br/publicacoes/regras\%20analise \%20sementes. pdf.

BRASIL. Instrução Normativa N.25, de 16 de dezembro de 2005. Padrões para produção e comercialização de sementes de soja. Diário Oficial da União, n.243 de 20 de dezembro de 2005, Brasília, DF, 20 de dezembro de 2005. www.agricultura.pr.gov.br/arquivos/File/PDF/padroes_soja.pdf

CAMOZZATO, V.A.; PESKE, S.T.; POSSENTI, J.C.; MENDES, A.S Desempenho de cultivares de soja em função do tamanho das sementes. Revista Brasileira de Sementes, v.31, n.1, p.288-292, 2009. http://www. scielo.br/scielo.php?pid=S0101-31222009000100032\&script $=$ sci_arttext

CARVALHO, N. M.; NAKAGAWA, J. Sementes: ciência, tecnologia e produção. 4. ed. Jaboticabal: FUNEP, 2000. 588 p.

DOURADO-NETO, D.; DARIO, G.J.A.; MARTIN, T.N.; SILVA, M. R.; PAVINATO, P.S.; HABITZREITER, T.L. Adubação mineral com cobalto e molibdênio na cultura da soja. Semina: Ciências Agrárias, v.33, p.2741-2752, 2012. http://www.uel.br/revistas/uel/index.php/semagrarias/article/view/8810 
EGLI, D.B. Timing of fruit initiation and seed size in soybean. Journal of Crop Improvement, v.26, n.6, p.751-766, 2012. http://www.tandfonline.com/ doi/abs/10.1080/15427528.2012.666784

EMBRAPA. Tecnologias de produção de soja - região central do Brasil 2012 e 2013. Londrina: Embrapa Soja, 2011. 262p. Embrapa Soja. Sistemas de Produção, n.15. http://www.cnpso.embrapa.br/download/SP15-VE.pdf

FERREIRA, D. F. SISVAR: um programa para análises e ensino de estatística. Revista Symposium, v. 6, p. 36-41, 2008. http://www.fadminas. org.br/symposium/12 edicoes/artigo 5.pdf

FRANCCA-NETO, J.B.; KRZYZANOWSKI, F. C.; COSTA, N.P. Teste de tetrazólio em sementes de soja. Londrina: EMBRAPA CNPSo, 1998. 72p. (Documentos. Embrapa Soja, 116).

GADOTTI, G.I.; FARIAS, C.R.J.; MENEGHELLO, G.E. Seed treatment of minor crops. Seed Science and Technology, v.34, n.1, p.129-138, 2012. http:// www.researchgate.net/publication/229090767_Seed_Treatment_of_Minor Crops www.researchgate.net/publication/Seed/9fcfd50ae515d29669.pdf †

GOULART, A.C.P. Tratamento de sementes de soja com fungicidas: recomendações técnicas. Dourados: EMBRAPA-CPAO, 1998. 32p. (Circular Técnica, 08).

HENNING, A.A.; FRANÇA-NETO, J.B.; KRZYZANOWSKI, F.C.; LORINI, I. Importância do tratamento de sementes de soja com fungicidas em safra 2010/2011, ano de "La Niña". Informativo ABRATES, v.20, n.1/2, p.55-61, 2010. http://www.abrates.org.br/portal/images/stories/informativos/ v20n12/artigo07.pdf

KRZYZANOWSKI, F.C.; FRANÇA-NETO, J.B.; COSTA, N.P. Teste do hipoclorito de sódio para sementes de soja. Londrina: Embrapa Soja, 2004. 4p. (Embrapa Soja. Circular Técnica, 37).

KRZYZANOWSKI, F.C.; HENNING, A.A.; FRANÇA-NETO, J.B.; LOPES, I.O.N.; ZORITA, M. D.; COSTA, N.P. Volume de calda com diferentes produtos para o tratamento de semente de soja e seu efeito sobre a qualidade fisiológica. Londrina: Embrapa Soja, 2007. p.48. (Embrapa Soja, Documentos, 290).

LIMA, T.C.; MEDINA, P. F.; FANAN, S. Avaliação do vigor de trigo pelo teste de envelhecimento acelerado. Revista Brasileira de Sementes, v.28, n.1, p.106-113, 2006. http://www.scielo.br/pdf/rbs/v28n1/a15v28n1.pdf
LUDWIG, M.P.; LUCCA FILHO, O.A.; BAUDET, L.; DUTRA, L.M.C.; AVELAR, S.A.G.; CRIZEL, R.L. Qualidade de sementes de soja armazenadas após recobrimento com aminoácido, polímero, fungicida e inseticida. Revista Brasileira de Sementes, v.33, n.3, p.395-406, 2011. http://www.scielo.br/ scielo.php?pid=S0101-31222011000300002\&script=sci_arttext

NAKAGAWA, J. Testes de vigor baseados na avaliação das plântulas. In: VIEIRA, R.D., CARVALHO, N.M. (Ed.). Testes de vigor em sementes. Jaboticabal: FUNEP, 1994. p.49-85.

NAKAGAWA, J. Testes de vigor baseados no desempenho das plântulas. In: KRZYZANOWSKI, F. C.; VIEIRA, R.D.; FRANÇA-NETO, J. B. (Ed.). Vigor de sementes: conceitos e testes. Londrina: ABRATES, 1999. cap. 2, p. 02-24.

OBANDO FLOR, E.P.; CICERO, S.M.; FRANÇA-NETO, J.B.; KRZYZANOWSKI, F.C. Avaliação de danos mecânicos em sementes de soja por meio da análise de imagens. Revista Brasileira de Sementes, v.26, n.01, p.68-76, 2004. http://www.scielo.br/scielo.php?script=sci arttext\&pid=S0101-31222004000100011

PÁDUA, G.P.; ZITO, R.K.; ARANTES, N.E.; FRANÇA-NETO, J.B Influência do tamanho da semente na qualidade fisiológica e na produtividade da cultura da soja. Revista Brasileira de Sementes, v.32, n.3, p. 9-16, 2010. http://www.scielo.br/pdf/rbs/v32n3/v32n3a01.pdf

PEREIRA, C.E.; GUIMARÃES, R.M.; VIEIRA, A.R.; EVANGELISTA, J.R.E.; OLIVEIRA, G.E. Tratamento fungicida e peliculização de sementes de soja submetidas ao armazenamento. Ciência Agrotécnica, v.35, n.1, p.158-164, 2011. http://www.scielo.br/scielo.php?script=sci arttext\&pid=S1413-70542011000100020

PEREIRA, C.E.; OLIVEIRA, J.A.; OLIVEIRA, G.E.; ROSA, M.C.M.; COSTA NETO, J. Tratamento fungicida via peliculização e inoculação de Bradyrhizobium em sementes de soja. Revista Ciência Agronômica, v.40, n.3, p.433-440, 2009.

SEDIYAMA, C. A. Z.; REIS, M.S.; SEDIYAMA, C.S.; DIAS, M.A.; SEDIYAMA, T.; DIAS, D. C.F.S. Physiological quality of soybean seed cultivars by osmoconditioning. Comunicata Scientiae, v.3, n.2, p. 90-97, 2012. http://comunicata.ufpi.br/index.php/comunicata/article/view/88 